\title{
Response of Escherichia coli 0157:H7, Listeria monocytogenes, Salmonella Typhimurium, and Staphylococcus aureus to the Thermal Stress Occurring in Model Manufactures of Grana Padano Cheese
}

\author{
D. Ercolini, ${ }^{1}$ V. Fusco, ${ }^{1}$ G. Blaiotta,${ }^{1}$ F. Sarghini, ${ }^{2}$ and S. Coppola ${ }^{1}$ \\ ${ }^{1}$ Dipartimento di Scienza degli Alimenti, Sezione di Microbiologia Agraria, Alimentare e Ambientale e di Igiene, and \\ ${ }^{2}$ Dipartimento di Ingegneria Agraria e Agronomia del territorio, Università degli Studi di Napoli Federico II, \\ Via Università 100, 80055 Portici, Italy
}

\begin{abstract}
The purpose of this research was to investigate the effect of temperature in the technology of production of Grana cheese against Escherichia coli O157:H7, Listeria monocytogenes, Salmonella Typhimurium, and Staphylococcus aureus. According to the technology of production, the cheese curds are cooked at $55^{\circ} \mathrm{C}$ and then cooled at room temperature $\left(25^{\circ} \mathrm{C}\right)$. A curd-cooling model was developed to estimate the temperature variation across the curd during cooling, and the thermal stress was applied to the pathogens according to the model in model-scale productions of Grana cheese artificially contaminated with approximately $10^{4} \mathrm{cfu} / \mathrm{mL}$ of the selected pathogens. According to the numerical results, the initial temperature inside the cheese is kept at almost the initial value (above $50^{\circ} \mathrm{C}$ ) for at least 4 $\mathrm{h}$ during cooling, whereas the crust of the curd cools rapidly to $30^{\circ} \mathrm{C}$ in the first hour. The best case was that of the core of the cheese where the high temperature was able to efficiently eliminate the contaminating pathogens. Moreover, the worst case was where the external ring of the curd in which a more rapid cooling allowed bacterial survival. Therefore, the thermal stress in the technology of production of Grana cheese can be only partially effective in the control of the selected pathogens. However, the whole technology of production includes other hurdles that can affect the survival of the pathogens and that need to be taken into account as a whole to evaluate the safety of Grana Padano cheese.
\end{abstract}

(Key words: food pathogen, raw milk cheese, Grana Padano cheese, thermal stress)

\section{INTRODUCTION}

A great variety of raw milk cheeses are produced through traditional dairy technologies and widespread

Received March 22, 2005.

Accepted July 7, 2005.

Corresponding author: Danilo Ercolini; e-mail: ercolini@unina.it. throughout the world. Cheese quality is greatly influenced by the complex microbial flora from the raw milk, which, together with that arising from the processing environment, contributes to milk acidification, curd production, and ripening, often leading to final products with distinctive flavors and taste (Cogan et al., 1997; Grappin and Beuvier, 1997; Mauriello et al., 2003). However, the untreated milk can be contaminated by pathogenic microorganisms, thus compromising the safety of the cheese and representing a hazard for consumers. In fact, some dairy technologies have been changed after food poisoning outbreaks; for example, in Stilton cheese, a wide intoxication of hypothesized staphylococcal origin occurred in 1989, and as a result, the technology shifted from raw to pasteurized milk (Maguire et al., 1991).

Escherichia coli $\mathrm{O} 157: \mathrm{H7}$, Listeria monocytogenes, Salmonella enterica serovar Typhimurium, and Staphylococcus aureus are important foodborne pathogens that are widely distributed throughout the environment. They have been associated with severe food poisoning outbreaks and are often found in milk and dairy products (De Valk et al., 2000; Rudol and Sherer, 2001; Araujo et al., 2002; Foschino et al., 2002; Haeghebaert et al., 2003; Conedera et al., 2004). The problem becomes increasingly relevant when raw milk cheeses are considered. Grana Padano cheese is one of the most popular raw milk cheeses; it is produced from semiskimmed raw milk by using natural whey cultures as starter. After coagulation, the curd is cooked at $54^{\circ} \mathrm{C}$ under whey, and the cheese mold, of about $40 \mathrm{~kg}$, is then ripened at about $15^{\circ} \mathrm{C}$ for 14 to 22 mo (Bottazzi, 1993). The core of the curd after draining, due in part to the microbial metabolic activity, is believed to reach a temperature of 55 to $56^{\circ} \mathrm{C}$ and to stay above $50^{\circ} \mathrm{C}$ for up to $10 \mathrm{~h}$ or more (Neviani et al., 1995; Pellegrino et al., 1997; Giraffa et al., 1998) so that alkaline phosphatase is inactivated in the core of the cheese (Pellegrino et al., 1995). This situation may result in a significant reduction of the microbial load and make the core safe from the presence of viable pathogens. On the other hand, the external part of the cheese cools more quickly 
and is less protected. Therefore, there is a differential distribution of the temperature within the curd that can exert a differential influence on the survival of possible contaminants depending on the considered portion of the dairy matrix.

The purpose of this research was to investigate the effect of the temperature in the technology of production of Grana cheese against $E$. coli O157:H7, L. monocytogenes, Salmonella Typhimurium, and Staph. aureus. A curd-cooling model was developed to estimate the temperature variation across the curd during cooling, and thermal stress was applied to the pathogens according to the model in model-scale productions of Grana cheese artificially contaminated with the selected pathogens.

\section{MATERIALS AND METHODS}

\section{Bacterial Strains and Growth Conditions}

The following bacterial strains were used in this study: E. coli O157:H7 strain 643 (USDA, Washington, DC), L. monocytogenes ScottA (from USDA-ARS Eastern Regional Research Center Culture Collection, Wyndmoor, PA), Salmonella Typhimurium F01 (from the culture collection of the Department of Food Science, Division of Microbiology, University of Naples Federico II), and Staph. aureus ATCC 14458 (American Type Culture Collection, Manassas, VA). The 4 strains were cultured in tryptone soy broth (Oxoid, Garbagnate Milanese, Italy) at $37^{\circ} \mathrm{C}$. Each strain was streaked on tryptone soy agar (Oxoid) plates before DNA extraction.

\section{Cooling Model}

Cooling history of Grana cheese was analyzed by performing a 3-D computational fluid dynamics simulation. Using a second-order finite volumes code, NavierStokes equations written in conservative form for mass continuity:

$$
\frac{\partial P}{\partial t}=\nabla \cdot(\rho \mathbf{v})=0
$$

momentum:

$$
\frac{\partial(\rho \mathbf{v})}{\partial t}+\nabla \cdot(\rho \mathbf{v} \otimes \mathbf{v})=-\nabla p+\nabla \cdot(\overline{\bar{\tau}})+\rho \mathbf{g},
$$

and energy:

$$
\frac{\partial(\rho E)}{\partial t}+\nabla \cdot(\mathbf{v}(\rho E+p))=\nabla \cdot(k \nabla T+\overline{\bar{\tau}} \cdot \mathbf{v}),
$$

were solved, where $\mathrm{E}$ is the total energy

$$
E=e+\frac{V^{2}}{2}
$$

$\mathbf{v}$ is the velocity vector, $\mathrm{T}$ is the temperature, $e=c_{v} T$ is the internal energy, $p$ is the static pressure, $\overline{\bar{\tau}}$ is the stress tensor, and $\rho \mathbf{g}$ is the gravitational force.

Geometrical configuration considered an isolated Grana curd inside a plastic mold and positioned over a steel table, with wheel radius, $R=44 \mathrm{~cm}$ and height, $\mathrm{H}=25 \mathrm{~cm}$.

The model included heat dissipation trough the steel base, the mold containing the cheese, and the natural convection cooling effects in the surrounding room; and consequently, equations 1 to 3 were solved coupled with the heat equations inside the solids (cheese, steel base, and plastic mold)

$$
\frac{\partial\left(\rho c_{p} T\right)}{\partial t}=\nabla \cdot(k \nabla T)
$$

where $c_{p}$ is the specific heat and $k$ is the solid conductivity. Biological heat production was not taken into account.

To speed up convergence, effect of buoyancy in the surrounding air was taken into account by introducing Boussinesq $\rho=\rho_{0}\left(1-\beta\left(T-T_{0}\right)\right)$ approximation to eliminate $\rho$ in the buoyancy term in the momentum equations, being $\beta$ the air thermal expansion coefficient.

Specific heat for the Grana cheese was chosen as a function of temperature and composition (Thomareis and Hardy, 1985) and set to $c_{p}=3.047 \mathrm{~kJ} /\left(\mathrm{kg}{ }^{\circ} \mathrm{C}\right)$, and thermal conductivity (Sweat and Parmelee, 1978) was set to $k=0.31 \mathrm{~W} / \mathrm{m}^{\circ} \mathrm{C}$. The time step $\Delta t$ was $2 s$ and to capture correctly natural convection effects the simulation required 150,000 control volumes.

\section{Grana Padano Cheese Manufacture}

The technology of manufacture of Grana Padano cheese was used to obtain curds of Grana cheese to subject to thermal conditions resembling the hot and the cold spot as suggested by the cooling model. Four separate model-scale productions of Grana cheese were performed in this work using semiskimmed raw milk artificially contaminated with $\sim 10^{4} \mathrm{cfu} / \mathrm{mL}$ of $E$. coli O157:H7, L. monocytogenes, Salmonella Typhimurium, and Staph. aureus, respectively. A uninoculated batch of raw milk was also processed and used as control. Each manufacture was performed twice $(n=2)$ from $500 \mathrm{~mL}$ of milk by addition of natural whey cultures for the production of Grana cheese (inoculum size $=3 \%$ ) and liquid rennet to obtain coagulation in $20 \mathrm{~min}$. The natural whey cultures where supplied by the Istituto Lattiero Caseario of Lodi and were cultures currently 
used for the production of Grana cheese. The cultures had an acidity of $30^{\circ} \mathrm{SH}$ (degrees Soxhlet-Henkel)/50 $\mathrm{mL}, \mathrm{pH} 3.4$, and a total lactic acid bacteria counts on de Man, Rogosa, Sharpe agar at $37^{\circ} \mathrm{C}$ of approximately $1.0 \times 10^{7} \mathrm{cfu} / \mathrm{mL}$. Once obtained, the curds were cooked at $55^{\circ} \mathrm{C}$ for $20 \mathrm{~min}$ and held under whey for $40 \mathrm{~min}$. At this point of the processing the curds had $\mathrm{pH} 5.70$ to 5.85. The curds were then drained and incubated in the appropriate conditions. Each contaminated preparation (one per pathogen) was performed in duplicate and once the contaminated curds were obtained, the 2 preparations were treated as follows: one curd was kept at $55^{\circ} \mathrm{C}$ for $7 \mathrm{~h}$ to simulate conditions of the core (best case) and the other was maintained at $45^{\circ} \mathrm{C}$ for $15 \mathrm{~min}$ followed by $38^{\circ} \mathrm{C}$ for $15 \mathrm{~min}$ to simulate conditions of the crust (worst case) of Grana cheese curd. Samples $(10 \mathrm{~g})$ were collected of raw milk, curd before and after cooking, and after 1,4 , and $7 \mathrm{~h}$ of curd incubation at $55^{\circ} \mathrm{C}$ in the best case and after $15 \mathrm{~min}$ at $45^{\circ} \mathrm{C}$ and 15 min at $38^{\circ} \mathrm{C}$ in the worst case. Quarter-strength Ringer's solution (Oxoid) was used for sample dilutions.

\section{Bacterial Enumeration}

Viable counts were performed by spread-plating in triplicate on selective media for the 4 pathogens (all media and supplements were purchased from Oxoid). Specifically, sorbitol MacConkey agar with BCIG (5bromo-4-chloro-3-indolo-b-D-glucuronide) was used for selective enumeration of $E$. coli O157:H7; Oxford agar with Listeria selective supplement (SR140E) for L. monocytogenes; Salmonella chromogenic agar base with Salmonella selective supplement (SR0194E) for Salmonella; and Baird-Parker agar with rabbit plasma fibrinogen supplement (SR122A) for Staph. aureus. The plates were incubated for $24 \mathrm{~h}$ at $37^{\circ} \mathrm{C}$ for $E$. coli O157:H7 and Salmonella, and for $48 \mathrm{~h}$ at $37^{\circ} \mathrm{C}$ for Staph. aureus and Listeria.

Thermal stressed cells were also detected. The thin agar layer method (Kang and Fung, 1999) modified according to Hajmeer et al. (2001) was used to count pathogen populations including live and stressed cells. Briefly, each curd sample was also plated in triplicate on resuscitation media consisting of plates containing $14 \mathrm{~mL}$ of the appropriate selective medium for each pathogen topped with a 14-mL layer of tryptone soy agar.

\section{Statistical Analysis}

The plate counts were expressed as means of the 2 trials. The data were analyzed by ANOVA (SPSS software, v. 11.0 for Mac; SPSS, Inc., Chicago, IL) to verify the differences between the samples during the manufacture and thermal treatment.

\section{DNA Extraction}

After plate counts, the plates were used for bulk cells formation as previously described (Ercolini et al., 2001). For each dilution, all colonies present on the surface of the plate were suspended in a suitable volume of quarter-strength Ringer's solution to reach 1 unit of optical density $(600 \mathrm{~nm})$, harvested with a sterile pipette, and stored frozen at $-20^{\circ} \mathrm{C}$ (Ercolini et al., 2001). When necessary, $1 \mathrm{~mL}$ of the bulk was used for DNA extraction as previously described (Ercolini et al., 2001). Briefly, the protocol described by the manufacturer of the Wizard DNA purification kit (Promega, Madison, WI) was applied as follows: $1 \mathrm{~mL}$ of sample was centrifuged at $14,000 \mathrm{rpm}$ for $5 \mathrm{~min}$ at $4^{\circ} \mathrm{C}$ and the resulting pellet was resuspended in $100 \mu \mathrm{L}$ of Tris-EDTA buffer (100 m $M$ TRIS, $10 \mathrm{~m} M$ EDTA). Then, $160 \mu \mathrm{L}$ of $0.5 M$ EDTA/ nuclei lysis solution (Wizard DNA purification kit, Promega) in 1:4.16 ratio, $5 \mu \mathrm{L}$ of RNAse $(10 \mathrm{mg} /$ $\mathrm{mL}$; Sigma, St. Louis, MO), and $10 \mu \mathrm{L}$ of proteinase $\mathrm{K}$ $(20 \mathrm{mg} / \mathrm{mL}$; Sigma) were added, and the mixture was incubated for $60 \mathrm{~min}$ at $37^{\circ} \mathrm{C}$. After incubation, 1 vol of ammonium acetate $(5 M)$ was added to the sample, which was then centrifuged at 22,000 $\times \mathrm{g}$ for $5 \mathrm{~min}$ at $4^{\circ} \mathrm{C}$. The supernatant was precipitated with 0.7 volumes of isopropanol and centrifuged at $22,000 \times g$ for $5 \mathrm{~min}$. Finally, the pellet was dried and resuspended in $50 \mu \mathrm{L}$ of DNA rehydration solution (Promega) by incubation at $55^{\circ} \mathrm{C}$ for $45 \mathrm{~min}$.

\section{PCR Amplifications}

For each pathogen, PCR amplifications were performed using target genes, primers, and conditions reported in Table 1. Amplifications were performed in a programmable heating incubator (MJ Research Inc., Watertown, MA). The final volume of each PCR mixture was $50 \mu \mathrm{L}$ when the target was $E$. coli $\mathrm{O} 157: \mathrm{H} 7$ or Salmonella, $25 \mu \mathrm{L}$ for Staph. aureus, and $20 \mu \mathrm{L}$ for $L$. monocytogenes. Regardless of the final volume, each mixture contained $2 \mu \mathrm{L}$ (about $50 \mathrm{ng}$ ) of template DNA, forward and reverse primer at a concentration of 0.2 $\mu M$, each deoxynucleoside triphosphate at a concentration of $0.25 \mathrm{~m} M, 2.5 \mathrm{~m} M \mathrm{MgCl}_{2}, 2.5 \mu \mathrm{L}$ of $10 \times$ PCR buffer, and $1.5 \mathrm{U}$ of Taq polymerase (Invitrogen, Milan, Italy). Polymerase chain reaction products were checked by agarose $(1.5 \% \mathrm{wt} / \mathrm{vol})$ gel electrophoresis at $7 \mathrm{~V} / \mathrm{cm}$ for $1.5 \mathrm{~h}$. The DNA template extracted from cultures of each pathogen was used as PCR positive control. The PCR assays were repeated at least twice to confirm the results.

\section{RESULTS AND DISCUSSION}

Initial temperature of the curd after draining was set at $55^{\circ} \mathrm{C}$, and the cheese cooling history was calcu- 


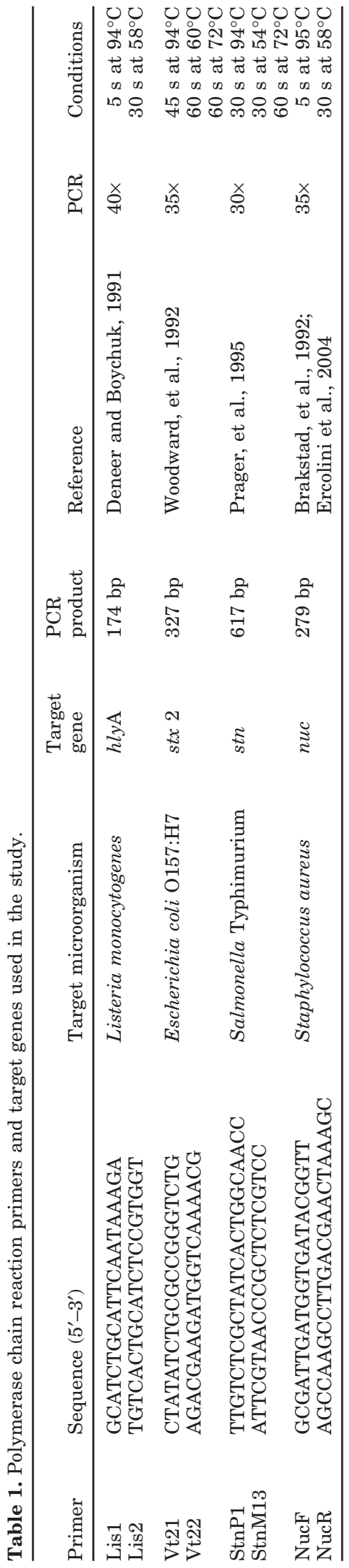

lated for the first $6 \mathrm{~h}$ to monitor the coldest spot. In Figure 1, a snapshot of temperature distribution, according to the model prediction, in different time steps is shown. On the upper cheese surface, 3 different zones are apparent: a first external ring (Figure $1 \mathrm{~B}$ and $\mathrm{C}$ ) where the effect of thermal plumes generated by natural convection is higher, an intermediate annular zone, and a central core where the cooling rate is slower. According to the numerical results, inside the cheese, the initial temperature was almost constant for at least $4 \mathrm{~h}$ as shown in Figure 1. It is interesting to note that, after the second hour, the coldest spot was no longer located on the upper surface in contact with the air, but in correspondence of the lowest external surface in contact with the steel plate (Figure 1C and D). Therefore, although the cooling initially takes place more rapidly on the surface of the curd in contact with the air, the cold spot is later located in the point of contact of the curd with the steel indicating a shift of cooling dynamics and of heat dissipation from convection to conduction.

The temperature distribution during cooling as predicted by this model could have an effect on the viability of microorganisms present in the dairy matrix. Therefore, an experiment was designed to simulate the thermal conditions predicted by the model in the different parts of the cheese curd and to evaluate their effect on the viability of the selected pathogens. Particularly, as shown in Figure 1, a best and a worst case could be defined. The best case was in the core of the cheese (Figure 1D), where the high temperature is able to affect the viability of microorganisms; whereas the worst case was in the external ring of the curd mold, where more rapid cooling takes place, and potentially allowing bacterial survival.

Model manufactures of Grana Padano cheese were performed as described earlier, and the fate of the contaminating pathogens was monitored in 2 different cases: 1$)$ the best case where the curds were kept at $55^{\circ} \mathrm{C}$, and 2) the worst case where the curds were incubated for defined times at defined cooling temperatures of the external curd ring as suggested by the cooling history. Particularly, the history suggested that the coldest spot in the external ring was $45^{\circ} \mathrm{C}$ after $15 \mathrm{~min}$ and $38^{\circ} \mathrm{C}$ after $30 \mathrm{~min}$; and therefore, the curds soon after cooking and draining were incubated at $45^{\circ} \mathrm{C}$ for $15 \mathrm{~min}$ and $38^{\circ} \mathrm{C}$ for additional $15 \mathrm{~min}$ to simulate the worst case.

The results are shown in Table 2 . All the plate counts were confirmed by appropriate species-specific PCR reactions using DNA template from bulk colonies of the last dilution plate. In all the cases, the last dilution bulk colonies were positive in the specific PCR reaction (Table 1), confirming that at least one colony of the last 

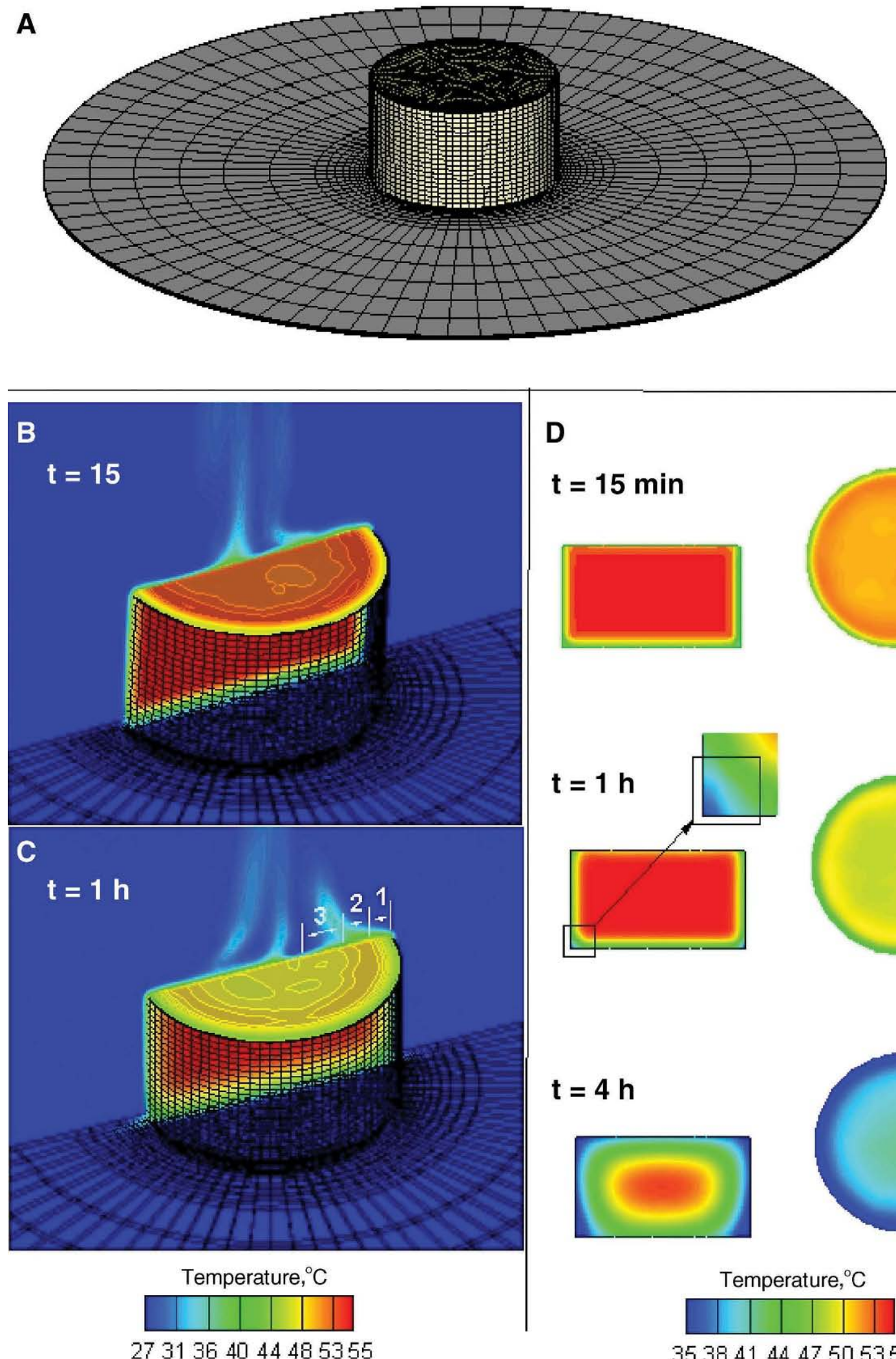

\section{D}

\section{$\mathbf{t}=15 \mathrm{~min}$}
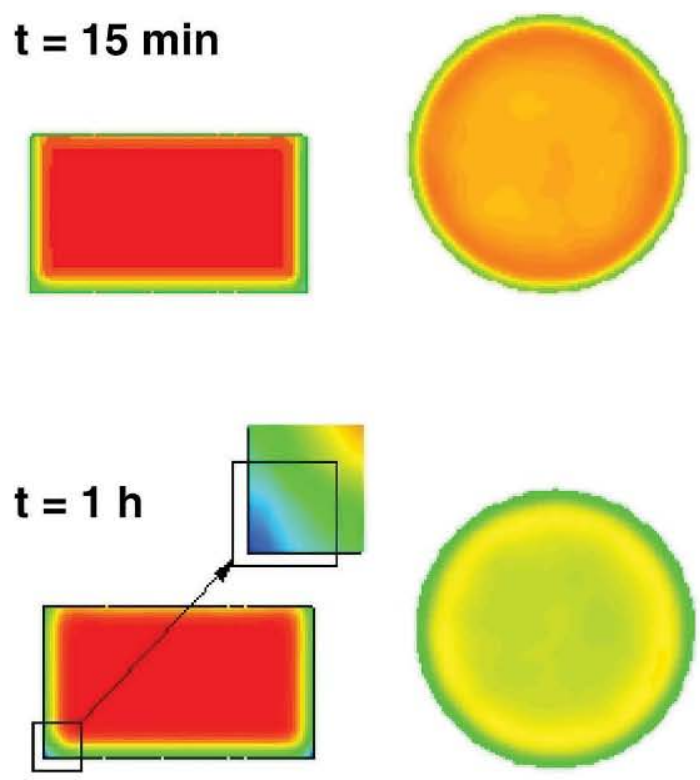

$\mathbf{t}=\mathbf{4 h}$
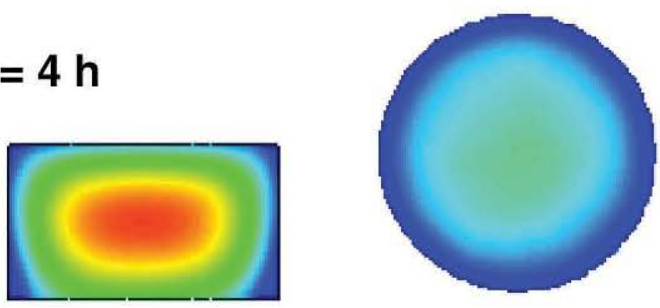

Temperature, ${ }^{\circ} \mathrm{C}$

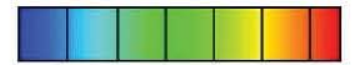

3538414447505355

Figure 1. Cooling history of Grana Padano cheese mold. A) computational grid; B) and C) effect of natural convection on Grana cooling; D) surface and internal temperature distribution at 3 different computational times. 
Table 2. Counts of Escherichia coli O157:H7, Listeria monocytogenes, Salmonella Typhimurium, and Staphylococcus aureus during the manufacture of Grana Padano cheese and during the cooling of the curd.

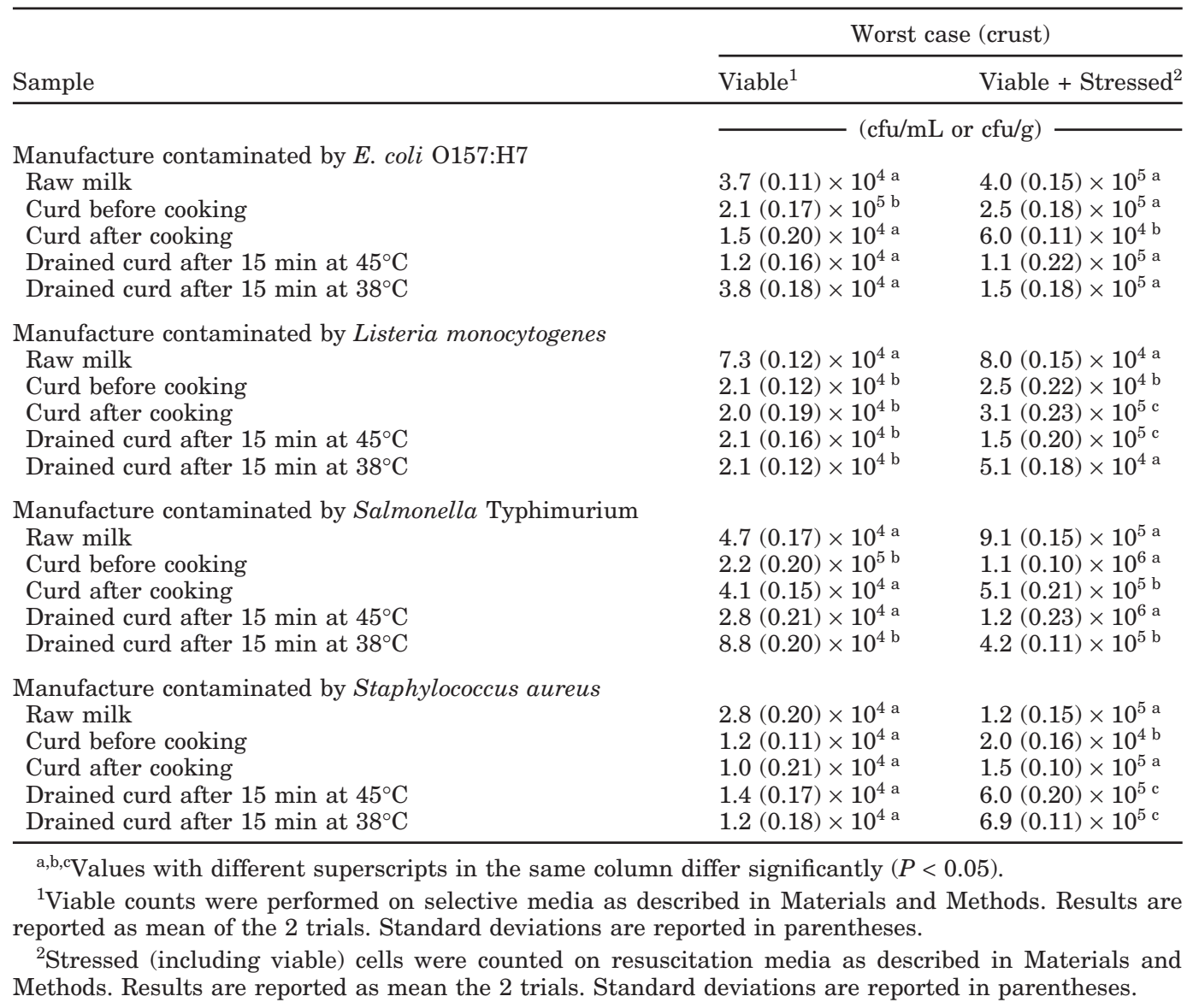

dilution plate belonged to the selected pathogens. None of the uninoculated control samples during processing was shown to contain the selected pathogens.

As shown in Table 2, the initial contamination of the raw milk was around $10^{4} \mathrm{cfu} / \mathrm{mL}$. The milk incubation for the production of the curd allowed bacterial growth in the case of $E$. coli and Salmonella (Table 2). The curd cooking step and the following resting step under whey determined a reduction of the viable cell loads for $E$. coli O157:H7 and Salmonella as result of the high cooking temperature. After curd cooking, Staph. aureus and L. monocytogenes remained at about the same level, but for all the pathogens, higher counts ( 1 log on average) were registered on the resuscitation media (Table 2). These results indicated that a first thermal stress is induced by the cooking procedure that is able by itself to affect the viability of the pathogens.

In the best-case experiment, the curds were kept at $55^{\circ} \mathrm{C}$ resembling the core of a real curd and the viable counts were performed at different times. Except for $E$. coli $\mathrm{O} 157: \mathrm{H} 7$ that survived at loads of about $10^{2}$ within the first $4 \mathrm{~h}$ of curd incubation at $55^{\circ} \mathrm{C}$, all other patho- gens remained undetectable after the first hour at $55^{\circ} \mathrm{C}$ (data not shown). The survival and growth of the pathogens in correspondence of the cold spot predicted by the model (worst case) was monitored for the first $30 \mathrm{~min}$ after curd draining and the results are displayed in Table 2. None of the pathogens showed a significant reduction during the first $15 \mathrm{~min}$ at $45^{\circ} \mathrm{C}$ and Salmonella increased in number after the additional $15 \mathrm{~min}$ at $38^{\circ} \mathrm{C}$. Generally, the counts on resuscitation media were about one log higher than those registered on selective media (Table 2) indicating that the thermal treatment generated at least $10^{5} \mathrm{cfu} / \mathrm{g}$ of stressed cells. However, although a certain amount of stressed cells was detected for Staph. aureus during the cooling in the cold spot, the counts on resuscitation and selective media gave the same response for $L$. monocytogenes (Table 2), indicating an absence of stressed Listeria in this case.

Similar studies performed on Parmigiano-Reggiano cheese, whose technology of production is almost identical to Grana Padano, demonstrated that the same pathogens considered in this study were not able to 
survive the technology of manufacture; and the authors of that study hypothesized a role of the cooking temperature and acidification by lactic acid bacteria as possible effective hurdles (Panari et al., 2001, 2004).

The results of this study indicated that the thermal treatments occurring during the production of Grana cheese could have a differential effect on the survival of bacterial pathogens according to the pathogen and to the zone of the curd mold where the pathogen is located. The centripetal temperature gradient in Grana cheese has previously been evaluated by other authors (Giraffa et al., 1998). That work examined the effect of temperature on the growth of thermophilic lactobacilli used as natural starters in Grana cheese, and highlighted that a differential growth and species distribution took place in response to the thermal stress. However, in that study, thermophilic species were considered, whereas none of the pathogens used in this study was thermophilic. In our case, it is likely that a survival distribution may be established across the curd according to site and temperature. The core may be regarded as safe area where a high temperature is maintained for a long time during cooling; the survival would increase at the edges of the cheese where the temperatures fall during cooling possibly allowing growth of the microorganisms. However, the whole technology of Grana Padano manufacture has to be taken into account along with the microbial ecology of the cheese to consider its safety. In fact, if the crust is a less protected area due to more rapid cooling of the curd, the crust is also the zone most promptly affected by the salting procedure. Salting is performed in saturated $\mathrm{NaCl}$ solutions for $10 \mathrm{~d}$ during which the curd loses $4 \%$ of its weight and absorbs 1.8\% of $\mathrm{NaCl}$ (Bottazzi, 1993). Therefore, the external parts of the curd are subjected to sudden osmotic stress that can affect the viability of the microorganisms with a gradient opposite to that of temperature. Moreover, $\mathrm{pH}$, ripening, and presence of a competitive lactic flora are other important factors possibly affecting the presence of pathogens. The thermophilic microflora of the natural whey cultures used as starter (Gatti et al., 1999; Lazzi et al., 2004) is able to cause a significant acidification providing $\mathrm{pH}$ values of 5.0 after $16 \mathrm{~h}$ from curd formation (Bottazzi, 1993), which represents a significant obstacle for pathogen growth and survival. In addition, the indigenous microbial flora of the raw milk can out-compete the pathogens during ripening. Furthermore, Grana Padano cheese is a long-ripened cheese; ripening lasts 14 to $22 \mathrm{mo}$ and the cheese reaches $\sim 30 \%$ moisture and 0.87 to 0.91 of water activity at the end of the ripening, which are adverse conditions for most bacteria. In conclusion, the thermal stress involved in the manufacture of Grana Padano cheese is able to affect the fate of $E$. coli
O157:H7, L. monocytogenes, Salmonella Typhimurium, and Staph. aureus; the pathogens are defeated by the high temperature in the central part of the cheese, but may survive the favorable thermal conditions on the crust. However, the whole technology of production of Grana cheese includes several obstacles that can affect survival of pathogens, and which need to be taken into account as a whole to evaluate the safety of Grana Padano cheese.

\section{ACKNOWLEDGMENTS}

This work was supported by a grant of MIUR-CNR, Rome, within the project "Agrobiotecnologie: Qualità, salubrità e sicurezza della produzione alimentare - Sicurezza Igienica di Formaggi Tipici Italiani”. Germano Mucchetti, Istituto Lattiero-Caseario of Lodi is acknowledged for providing the natural whey cultures. We would like to thank Paolo Masi, Dipartimento di Scienza degli Alimenti, Università degli studi di Napoli Federico II, for his contribution to this work.

\section{REFERENCES}

Araujo, V. S., V. A. Pagliares, M. L. Queiroz, and A. C. FreitasAlmeida. 2002. Occurrence of Staphylococcus and enteropathogens in soft cheese commercialized in the city of Rio de Janeiro, Brazil. J. Appl. Microbiol. 92:1172-1177.

Bottazzi, V. 1993. Applicazioni biotecnologiche di microrganismi lattiero-caseari. Pages 253-274 in Microbiologia Lattiero-casearia. Edagricole, Bologna, Italy.

Brakstad, O. G., K. Aasbakk, and J. A. Maelamd. 1992. Detection of Staphylococcus aureus by polymerase chain reaction amplification of nuc gene. J. Clin. Microbiol. 30:1654-1660.

Cogan, T. M., M. Barbosa, E. Beuvier, B. Bianchi-Salvadori, P. S. Cocconcelli, I. Fernandes, J. Gomez, R. Gomez, G. Kalantzopoulos, A. Ledda, M. Medina, M. C. Rea, and E. Rodriguez. 1997. Characterisation of the lactic acid bacteria in artisanal dairy products. J. Dairy Res. 64:409-421.

Conedera, G., P. Dalvit, M. Martini, G. Galiero, M. Gramaglia, E. Goffredo, G. Loffredo, S. Morabito, D. Ottaviani, F. Paterlini, G. Pezzotti, M. Pisanu, P. Semprini, and A. Caprioli. 2004. Verocytotoxin-producing Escherichia coli 0157 in minced beef and dairy products in Italy. Int. J. Food Microbiol. 96:67-73.

Deneer, H. G., and I. Boychuk. 1991. Species-specific detection of Listeria monocytogenes by DNA amplification. Appl. Environ. Microbiol. 57:606-609.

De Valk, H., E. Delarocque-Astagneau, G. Colomb, S. Ple, E. Godard, V. Vaillant, S. Haeghebaert, P. H. Bouvet, F. Grimont, P. Grimont, and J. C. Desenclos. 2000. A community-wide outbreak of Salmonella enterica serotype Typhimurium infection associated with eating a raw milk soft cheese in France. Epidemiol. Infect. 124:1-7.

Ercolini, D., G. Blaiotta, V. Fusco, and S. Coppola. 2004. PCR-based detection of enterotoxigenic Staphylococcus aureus in the early stages of raw milk cheese making. J. Appl. Microbiol. 96:10901096.

Ercolini, D., G. Moschetti, G. Blaiotta, and S. Coppola. 2001. The potential of a polyphasic PCR-DGGE approach in evaluating microbial diversity of Natural Whey Cultures for water-buffalo Mozzarella cheese production: Bias of "culture dependent" and "culture independent" approaches. Syst. Appl. Microbiol. 24:610-617.

Foschino, R., A. Invernizzi, R. Barucco, and K. Stradiotto. 2002. Microbial composition, including the incidence of pathogens, of goat 
milk from the Bergamo region of Italy during a lactation year. J. Dairy Res. 69:213-225.

Gatti, V., G. Contarini, and E. Neviani. 1999. Effectiveness of chemometric techniques in discrimination of Lactobacillus helveticus biotypes from natural dairy starter cultures on the basis of phenotypic characteristics. Appl. Environ. Microbiol. 65:1450-1454.

Giraffa, G., L. Rossetti, G. Mucchetti, F. Addeo, and E. Neviani. 1998. Influence of the temperature gradient on the growth of thermophilic lactobacilli used as natural starters in Grana cheese. J. Dairy Sci. 81:31-36.

Grappin, R., and E. Beuvier. 1997. Possible implications of milk pasteurization on the manufacture and sensory quality of ripened cheese. Int. Dairy J. 7:751-761.

Haeghebaert, S., P. Sulem, L. Deroudille, E. Vanneroy-Adenot, O. Bagnis, P. Bouvet, F. Grimont, A. Brisabois, F. Le Querrec, C. Hervy, E. Espie, H. De Valk, and V. Vaillant. 2003. Two outbreaks of Salmonella enteriditis phage type 8 linked to the consumption of Cantal cheese made with raw milk, France 2001. Euro Surveill. 8:151-156.

Hajmeer, M. N., D. Y. C. Fung, J. L. Marsden, and G. A. Milliken. 2001. Effects of preparation method, age, and plating technique of thin agar layer media on recovery of Escherichia coli O157:H7 injured by sodium cloride. J. Microbiol. Meth. 47:249-253.

Kang, D. H., and D. Y. C. Fung. 1999. Thin agar layer method for recovery of heat-injured Listeria monocytogenes. J. Food Prot. 62:1346-1349.

Lazzi, C., L. Rossetti, M. Zago, E. Neviani, and G. Giraffa. 2004. Evaluation of bacterial communities belonging to natural whey starters for Grana Padano cheese by length heterogeneity-PCR. J. Appl. Microbiol. 96:481-490.

Maguire, H. C., M. Boyle, M. J. Lewis, J. Pankhurst, A. A. Wieneke, M. Jacob, J. Bruce, and M. O'Mahony. 1991. A large outbreak of food poisoning of unknown aetiology associated with Stilton cheese. Epidemiol. Infect. 106:497-505.

Mauriello, G., L. Moio, A. Genovese, and D. Ercolini. 2003. Relationships between flavoring capabilities, bacterial composition and geographical origin of Natural Whey Cultures (NWC) used for traditional water-buffalo Mozzarella cheese manufacture. J. Dairy Sci. 86:486-497.

Neviani, E., R. Divizia, E. Abbiati, and M. Gatti. 1995. Acidification activity of thermophilic lactobacilli under the temperature gradient of Grana cheese making. J. Dairy Sci. 78:1248-1252.

Panari, G., M. Pecorari, G. Merialdi, and M. Dottori. 2004. The behaviour of potentially pathogenic bacteria in the production of Parmigiano-Reggiano cheese. Sci. Tecn. Latt. Cas. 55:137-146.

Panari, G., S. Perini, R. Guidetti, M. Pecorari, G. Merialdi, and A. Albertini. 2001. Indagine sul comportamento di germi patogeni nella tecnologia del formaggio Parmigiano-Reggiano. Sci. Tecn. Latt. Cas. 52:13-22.

Pellegrino, L., G. Battelli, P. Resmini, P. Ferranti, F. Barone, and F. Addeo. 1997. Effects of heat load gradient occurring in moulding on the characterization and ripening of Grana Padano. Lait $77: 217-228$.

Pellegrino, L., P. Resmini, and U. Fantuzzi. 1995. Evaluation and interpretation of phosphatase activity in the control of Grana Padano and Parmiggino Reggiano cheese. Ind. Latte 31:17-30.

Prager, R., A. Fruth, and H. Tschape. 1995. Salmonella enterotoxin (stn) gene is prevalent among strains of Salmonella enterica, but not among Salmonella bongori and other Enterobacteriaceae. FEMS Immunol. Med. Microbiol. 12:47-50.

Rudol, M., and S. Sherer. 2001. High incidence of Listeria monocytogenes in European red smear cheese. Int. J. Food Microbiol. 63:91-98.

Sweat, V. E., and C. E. Parmelee. 1978. Measurement of thermal conductivity of dairy products and margarines. J. Food Process Eng. 2:187-197.

Thomareis, A. S., and J. Hardy. 1985. Evolution de le chaleur specifique apparentes des fromages fondues entre 40 et $100^{\circ} \mathrm{C}$. Influence de leur composition. J. Food Eng. 4:117-134.

Woodward, M. J., P. J. Carroll, and C. Wray. 1992. Detection of entero- and verocyto-toxin genes in Escherichia coli from diarrhoeal disease in animals using the polymerase chain reaction. Vet. Microbiol. 31:251-261. 